\title{
Radiolabelled cyanidin 3-O-glucoside is poorly absorbed in the mouse
}

\author{
Catherine Felgines $^{1 *}$, Stéphanie Krisa ${ }^{2}$, Aurélie Mauray ${ }^{3}$, Catherine Besson ${ }^{3}$, Jean-Louis Lamaison ${ }^{1}$, \\ Augustin Scalbert ${ }^{3}$, Jean-Michel Mérillon ${ }^{2}$ and Odile Texier ${ }^{1}$ \\ ${ }^{1}$ Laboratoire de Pharmacognosie et Phytothérapie, Faculté de Pharmacie, Université Clermont 1, 28 Place Henri Dunant, BP 38, \\ F-63001 Clermont-Ferrand Cedex 1, France \\ ${ }^{2}$ Groupe d'Etude des Substances Végétales à Activité Biologique, Institut des Sciences de la Vigne et du Vin, Université de \\ Bordeaux, F-33882 Villenave d'Ornon, France \\ ${ }^{3}$ Unité de Nutrition Humaine, Institut National de la Recherche Agronomique, Clermont-Ferrand/Theix, Saint-Genès-Champanelle \\ F-63122, France \\ (Received 23 September 2009 - Revised 14 December 2009 - Accepted 15 December 2009 - First published online 26 February 2010$)$
}

\begin{abstract}
Anthocyanins are natural pigments abundant in various fruits and berries that are involved in the prevention of various chronic diseases. Their low concentrations in plasma and urine are explained in part by their complex chemistry and the formation of still uncharacterised metabolites. The aim of the present study was to follow the distribution of anthocyanins in the body using ${ }^{14} \mathrm{C}$-labelled cyanidin 3 - $O$-glucoside $(\mathrm{Cy} 3 \mathrm{G})$ fed by gavage to mice. After the administration of $22.2 \mathrm{kBq}{ }^{14} \mathrm{C}-\mathrm{Cy} 3 \mathrm{G}(0.93 \mathrm{mg})$, radioactivity was detected in most organs tested over the following $24 \mathrm{~h}$ with a peak observed in inner tissues at $3 \mathrm{~h}$. The major fraction of the radioactivity (44.5\%) was found in the faeces collected $24 \mathrm{~h}$ after ingestion. At $3 \mathrm{~h}$ after oral administration of $141 \mathrm{kBq}{ }^{14} \mathrm{C}-\mathrm{Cy} 3 \mathrm{G}(4.76 \mathrm{mg})$, most of the radioactivity $(87.9 \%$ of intake) was recovered in the gastrointestinal (GI) tract, especially in the small intestine $(50.7 \%)$ and the caecum $(23 \%)$. At this time, $3.3 \%$ of the radioactivity was detected in urine. There was minimal accumulation $(0.76 \%)$ of radioactivity in tissues outside the GI tract. Distribution of radioactivity varied among organs, with liver, gallbladder and kidneys showing the highest radioactivity. Taken as a whole, these results show that Cy3G is poorly absorbed in the mouse.
\end{abstract}

Anthocyanins: ${ }^{14} \mathrm{C}$-labelled cyanidin 3-glucoside: Mice: Tissue distribution: Gastrointestinal tract

Anthocyanins, which belong to the flavonoid family, are reddish natural pigments occurring ubiquitously in fruits and berries $^{(1)}$. Their average daily intake was estimated at about $12.5 \mathrm{mg} / \mathrm{d}$ in the United States and at $47 \mathrm{mg} / \mathrm{d}$ in Finland ${ }^{(2,3)}$. However, high intakes $(>100 \mathrm{mg} / \mathrm{d})$ could be easily achieved with regular consumption of red fruits or berries. Natural food colourants rich in anthocyanins may also significantly contribute to the total anthocyanin dietary intake ${ }^{(4)}$.

Anthocyanins have been reported to promote health and prevent various chronic diseases ${ }^{(5,6)}$. They may reduce the risk of CVD, exert anticarcinogenic and neuroprotective activities, reduce inflammatory insult and modulate the immune response ${ }^{(7-11)}$. They are also reported to exert antidiabetic and antiobesity effects ${ }^{(12,13)}$.

Health-enhancing properties of anthocyanins depend on their absorption, metabolism, tissue distribution and excretion. In the last few years, a number of studies have been conducted on the absorption of anthocyanins in human subjects or experimental animals (for review, see reference ${ }^{(14)}$ ). Most of them reported that the proportion of total anthocyanins absorbed and excreted in the urine (in the native form and as metabolites) was below $1 \%$ of the ingested amount, which is lower than that found for most flavonoids ${ }^{(5,14)}$. Anthocyanins are rapidly absorbed from both stomach and small intestine, and they appear in blood circulation and urine as intact, methylated, glucurono- and/or sulphoconjugated forms ${ }^{(15-19)}$. Knowledge on tissue distribution of various anthocyanin metabolites is important in understanding the mechanisms by which health effects could occur. However, to date, little is known about their distribution outside the digestive tract. In rats, a few studies have shown the presence of anthocyanins in some organs such as liver, kidney, brain and eyes ${ }^{(20-24)}$. We have recently shown that anthocyanin feeding in rats resulted in the distribution of anthocyanin metabolites (native as well as glucurono and/or methylated anthocyanins) to several organs (prostate, bladder, testes, adipose tissue and heart) albeit at low concentrations ${ }^{(25)}$. Recent studies in mice have also detected anthocyanins in various tissues such as liver, kidney, prostate, testes and lungs ${ }^{(26,27)}$. Most authors have suggested that other metabolites may also be present in organs, but to date, they are unidentified and their amounts are unknown. Indeed, anthocyanin chemistry is complex, and anthocyanins could be converted into colourless forms that are not detected owing to their chemical instability at physiological $\mathrm{pH}^{(28)}$ or metabolised into various compounds such as phenolic acids ${ }^{(29-31)}$. 
The aim of the present work was thus to follow anthocyanin distribution in mice after oral administration of a radiolabelled substrate, ${ }^{14} \mathrm{C}$-cyanidin 3 - $O$-glucoside $(\mathrm{Cy} 3 \mathrm{G})$. Cy3G was chosen as it was the most representative dietary anthocyanin. We first followed the radioactivity derived from the labelled anthocyanin in tissues over a $24 \mathrm{~h}$ period. Next, we tentatively established a complete evaluation of the recovery of radioactivity $3 \mathrm{~h}$ after the administration of a higher amount of ${ }^{14}$ C-labelled Cy3G.

\section{Materials and methods}

\section{Chemicals}

L-[U-ring- $\left.{ }^{14} \mathrm{C}\right]-$ Phenylalanine was purchased from Isobio (Fleurus, Belgium) and isopropanol from Atlantic Labo (Bruges, France) and methyl jasmonate and $\mathrm{H}_{2} \mathrm{O}_{2}$ were purchased from Sigma-Aldrich (St-Quentin Fallavier, France). Hionic-Fluor liquid scintillation cocktail and Soluene-350 were obtained from Perkin Elmer (Courtaboeuf, France). $\mathrm{Cy} 3 \mathrm{G}$ and malvidin 3-O-glucoside were purchased from Extrasynthèse (Genay, France). Blackberry anthocyanin extract was supplied by Ferlux-Mediolanum (Cournon d'Auvergne, France).

\section{Radiotracer production}

${ }^{14} \mathrm{C}-\mathrm{Cy} 3 \mathrm{G}$ was obtained as described previously ${ }^{(32)}$. Briefly, the L-[U-ring- $\left.{ }^{14} \mathrm{C}\right]$-phenylalanine $(92.5 \mathrm{kBq} / \mathrm{ml}$ of cell suspension) and unlabelled phenylalanine (final concentration of $0.5 \mathrm{~mm})$ were added to grape cell suspension culture $(50 \mathrm{ml})$ on days 6 and 8 . Methyl jasmonate $(10 \mu \mathrm{M})$ was applied on day 6 . Then, anthocyanins were extracted from cells harvested on day 14 , and $\mathrm{Cy} 3 \mathrm{G}$ was purified by a combination of chromatographic techniques ${ }^{(32)}$. The purity of ${ }^{14} \mathrm{C}$-labelled $\mathrm{Cy} 3 \mathrm{G}$ was estimated by HPLC analysis, and it was over $97 \%$. The specific radioactivity of ${ }^{14} \mathrm{C}-\mathrm{Cy} 3 \mathrm{G}$ used for the two experiments described below (study over time and study of tissue distribution) was 23.9 and $29.5 \mathrm{MBq} / \mathrm{g}$, respectively. Given the position of the ${ }^{14} \mathrm{C}$ on phenylalanine and the anthocyanin biosynthetic pathway ${ }^{(33)}$, Cy3G was labelled on its B-ring (Fig. 1). ${ }^{14} \mathrm{C}-\mathrm{Cy} 3 \mathrm{G}$ was dissolved in water immediately before administration.

\section{Animals}

Male Balb/c mice of 10 weeks of age weighing approximately $23 \mathrm{~g}$ (Charles River, L'Arbresle, France) were maintained in a

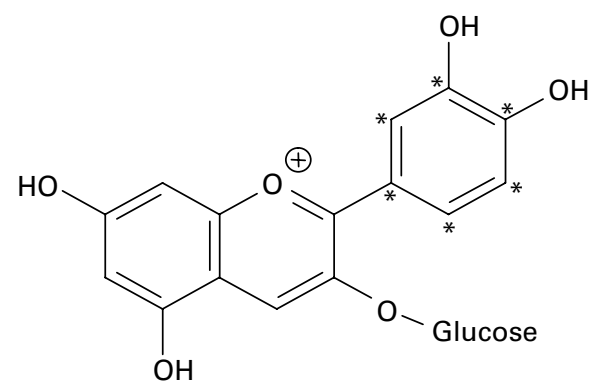

Fig. 1. Structure of ${ }^{14} \mathrm{C}$-labelled cyanidin 3 -O-glucoside. ${ }^{* 14} \mathrm{C}$-labelled positions. temperature-controlled room with a dark period from 08.00 to 20.00 hours. They were fed ad libitum with a standard chow (113, SAFE, Augy, France) and water for at least 1 week before the experiments. For the first experiment (study over a $24 \mathrm{~h}$ period), mice ( $n$ 12) were kept in wire-bottomed cages. For the second experiment, mice (n 3) were individually housed in metabolic cages fitted with urine/faeces separators. Mice were deprived of food for $16 \mathrm{~h}$ before the administration of the radiolabelled anthocyanin, and they were maintained and handled according to the recommendations of the Institutional Ethics Committee in accordance with the French decree no. 87-848.

\section{Radiolabelled anthocyanin administration and sampling procedure}

In the first experiment (study over a $24 \mathrm{~h}$ period), mice $(n 12)$ received $0.7 \mathrm{ml}$ of a ${ }^{14} \mathrm{C}-\mathrm{Cy} 3 \mathrm{G}$ solution by direct stomach intubation. Each mouse received $22.2 \mathrm{kBq}{ }^{14} \mathrm{C}-\mathrm{Cy} 3 \mathrm{G}$ $(0.93 \mathrm{mg})$. Mice were then sacrificed at various times post administration $(1,3,6$ or $24 \mathrm{~h}, n 3$ per time). Mice sacrificed $24 \mathrm{~h}$ after anthocyanin administration had access to food from $4 \mathrm{~h}$ after the gavage.

In the second experiment (tissue distribution), mice (n 3 ) received $0.7 \mathrm{ml}$ of a ${ }^{14} \mathrm{C}-\mathrm{Cy} 3 \mathrm{G}$ solution containing $141 \mathrm{kBq}$ ${ }^{14} \mathrm{C}-\mathrm{Cy} 3 \mathrm{G}(4.76 \mathrm{mg})$ by direct stomach intubation, and they were then sacrificed $3 \mathrm{~h}$ after anthocyanin administration.

Anthocyanin intake corresponds to about a $110-600 \mathrm{mg} / \mathrm{d}$ intake in human consumers, which is an amount corresponding to less than two servings of blackberries ${ }^{(2)}$.

At the end of the experimental period, mice were sacrificed after being anaesthetised with sodium pentobarbital ( $40 \mathrm{mg} / \mathrm{kg}$ body weight). All the blood was withdrawn from the abdominal aorta into heparinised tubes. Plasma and erythrocytes were separated by centrifugation at $12000 \mathrm{~g}$ for $5 \mathrm{~min}$. Intracardiac perfusion of a $\mathrm{NaCl}$ solution $(5 \mathrm{ml} ; 0 \cdot 15 \mathrm{M})$ allowed to remove residual blood from the tissues. Inner tissues (liver, kidneys, heart, gallbladder, lungs, epididymal adipose tissue, brain, cerebellum, thymus, prostate gland, testes, gastrocnemius muscle, spleen, bladder, eyes and pancreas) were collected from bloodless mice and weighed.

In the first experiment, stomach, a fraction of small intestine (duodenum) and caecum were collected and washed with deionised water, and radioactivity was analysed in these tissues as described below. Bladder was removed with its urine content, and faeces were collected.

In the second experiment, stomach, whole small intestine, caecum and colon were removed. The contents of the stomach, caecum and colon were collected from their respective organ by washing twice with $0.5 \mathrm{ml}$ of $0.15 \mathrm{M}-\mathrm{NaCl}$. These contents and organs were analysed separately for radioactivity counting. On account of the difficulty in washing small intestine, whole small intestine (i.e. wall and content) was crushed using a homogeniser (Ultra-Turrax) in $1 \mathrm{ml}$ of $0 \cdot 15 \mathrm{M}-\mathrm{NaCl}$, and three aliquots were analysed for radioactivity content. In this experiment, urine was collected from the bladder by puncture and from the metabolic cage after it was rinsed with $500 \mu \mathrm{l}$ of distilled water, and analysed separately. Faeces were also collected. 


\section{Non-labelled anthocyanin administration and sampling} procedure

Mice ( $n$ 12) received $0.7 \mathrm{ml}$ of a blackberry anthocyanin solution by direct stomach intubation, and were sacrificed $3 \mathrm{~h}$ later. The blackberry anthocyanin solution was obtained by dissolution of the blackberry extract at a concentration of $11.2 \mathrm{mg} / \mathrm{ml}$ in water. Hence, the mice received $3.03 \mathrm{mg}$ $(6.26 \mu \mathrm{mol})$ of $\mathrm{Cy} 3 \mathrm{G}$ equivalents. The blackberry extract contained $38.7 \%$ anthocyanins. They are only derivatives of cyanidin, with Cy3G being the main anthocyanin $(90 \%)^{(20)}$.

At the end of the experimental period, mice were sacrificed after being anaesthetised with sodium pentobarbital $(40 \mathrm{mg} / \mathrm{kg}$ body weight). All the blood was withdrawn from the abdominal aorta into heparinised tubes. Blood samples were centrifuged at $12000 \mathrm{~g}$ for $5 \mathrm{~min}$, and the plasma was removed. Urine was collected from the metabolic cage after it was rinsed with $500 \mu$ l of distilled water. When present, urine was collected from the bladder and pooled with the urine collected from the cage. Urine and plasma samples were acidified with $240 \mathrm{mM}-\mathrm{HCl}$ and stored at $-20^{\circ} \mathrm{C}$ until $\mathrm{HPLC}$ analysis.

\section{Radioactivity quantification}

Whole organs (weight $<150 \mathrm{mg}$ ) or aliquots were digested immediately after collection. Plasma, erythrocytes, faeces and urine samples were treated in the same manner. Digestion of organs was carried out with $2 \mathrm{ml}$ of Soluene-350 for $4 \mathrm{~h}$ at $50^{\circ} \mathrm{C}$. Then, $0 \cdot 2-0.5 \mathrm{ml}$ of $\mathrm{H}_{2} \mathrm{O}_{2}$ was added until a clear solution was obtained. Absolute quantification of radioactivity in selected organs and biological liquids was performed by scintillation counting. Radioactivity was determined after colour quench correction by adding $10 \mathrm{ml}$ of Hionic-Fluor liquid scintillation cocktail to each sample. Counts were measured three times over a $10 \mathrm{~min}$ period each in a Tricarb $2200 \mathrm{CA}$ liquid scintillation counter (Perkin Elmer), and were corrected for background (estimated at $20 \mathrm{dpm}$ ). The counting efficiency was on average $96 \%$. Radioactivity was detected in all the studied organs at levels clearly higher than the background one.

\section{HPLC analysis}

Urine samples were centrifuged at $12000 \mathrm{~g}$ for $5 \mathrm{~min}$, and the supernatant $(20 \mu \mathrm{l})$ was injected and analysed by HPLC as described below.

Plasma anthocyanins were extracted with a Sep-Pak $\mathrm{C}_{18}$ Plus solid-phase extraction cartridge (Waters, Milford, MA, USA) as described previously ${ }^{(19)}$ using malvidin 3-O-glucoside as the internal standard, and were then analysed by HPLC $(60 \mu 1)$.

Analysis of anthocyanins was performed by HPLC using a UV-vis detector (785A; Perkin-Elmer) at $524 \mathrm{~nm}$. Samples were loaded onto an Uptisphere 3 ODB $\mathrm{C}_{18} 3-\mu \mathrm{m}$ column $(150 \times 4.6 \mathrm{~mm}$ internal diameter $)$ protected by an Uptisphere 3 ODB $\mathrm{C}_{18} 3-\mu \mathrm{m}$ guard column $(10 \times 4 \mathrm{~mm}$ internal diameter; Interchim, Montluçon, France). Elution was done using water $-\mathrm{H}_{3} \mathrm{PO}_{4}(99: 1)$ as solvent $\mathrm{A}$ and acetonitrile as solvent $\mathrm{B}$ at a flow rate of $1.0 \mathrm{ml} / \mathrm{min}$. Analyses were carried out with linear gradient conditions from 100 to $90 \%$ A for $10 \mathrm{~min}$ and then to $75 \% \mathrm{~A}$ for $30 \mathrm{~min}$. Anthocyanin concentrations are expressed as $\mathrm{Cy} 3 \mathrm{G}$ equivalents.

\section{Statistical analysis}

Values are given as means with their standard errors. Significant differences between means were determined by one-way ANOVA followed by the Student-Newman-Keuls test (GraphPad, Instat, San Diego, CA, USA).

\section{Results}

Distribution of radioactivity in various tissues was determined after the administration of $22.2 \mathrm{kBq}{ }^{14} \mathrm{C}-\mathrm{Cy} 3 \mathrm{G}$ in mice and sacrifice at various times post administration (Fig. 2). The amount of radioactivity in stomach and duodenum decreased from $1 \mathrm{~h} 30 \mathrm{~min}$ to $24 \mathrm{~h}$, whereas in most of the other organs, the highest radioactivity was detected $3 \mathrm{~h}$ after ${ }^{14} \mathrm{C}-\mathrm{Cy} 3 \mathrm{G}$ administration, and it decreased thereafter to become very low $24 \mathrm{~h}$ after the ingestion. In some organs (heart, thymus, spleen, brain, cerebellum, eyes and muscle), the amount of radioactivity was very low throughout the experiment (data not shown). The amount of radioactivity detected in the tissues outside the gastrointestinal (GI) tract accounted for $0.74,1.44,0.55$ and $0.17 \%$ of the administered dose at $1 \mathrm{~h} 30 \mathrm{~min}, 3 \mathrm{~h}, 6 \mathrm{~h}$ and $24 \mathrm{~h}$ post administration, respectively. No radioactivity was detected in faeces collected $1 \mathrm{~h} 30 \mathrm{~min}$ and $3 \mathrm{~h}$ after ${ }^{14} \mathrm{C}-\mathrm{Cy} 3 \mathrm{G}$ administration. However, 9.5 and $44.5 \%$ of the ingested amount was associated with faecal materials collected 6 and $24 \mathrm{~h}$ after the ingestion, respectively.

Tissue distribution of radioactivity was then evaluated more thoroughly in mice that received a higher amount of radioactivity $\left(141 \mathrm{kBq}{ }^{14} \mathrm{C}-\mathrm{Cy} 3 \mathrm{G}\right.$ per mouse). Animals were sacrificed $3 \mathrm{~h}$ later. The entire GI tract and urine were collected and analysed in order to establish a complete evaluation of radioactivity recovery. After $3 \mathrm{~h}$, most of the radioactivity (87.9\% of intake) was in the GI tract, especially in the small intestine $(50.7 \%)$ and caecum (23\%; Table 1). At this time, $3.3 \%$ of the radioactivity was recovered in urine (Table 2). There was a minimal accumulation of radioactivity in tissues outside the GI tract, with the total amount of radioactivity in these tissues being $0.76 \%$ of the ingested amount (Table 2). Distribution of radioactivity varied among organs, with liver, gallbladder and kidneys showing the highest counts. No radioactivity was detected in faeces collected $3 \mathrm{~h}$ after administration. A total amount of 128 (SEM 3) kBq (92.0 (SEM 1.1)\% of the administered radioactivity) was recovered in these mice.

To evaluate the proportion of anthocyanin metabolites with an intact flavylium skeleton (absorbing at $524 \mathrm{~nm}$ ) present in urine and plasma, a blackberry anthocyanin extract, as a source of $\mathrm{Cy} 3 \mathrm{G}$, was administered to mice. Plasma and urine were collected $3 \mathrm{~h}$ after the administration of blackberry anthocyanins and were analysed by HPLC (Fig. 3). The total urinary excretion of anthocyanins accounted for $1 \cdot 1$ (SEM $0 \cdot 1) \%(n 3)$ of anthocyanin intake. Total amount of anthocyanins detected in plasma was $0.45 \mathrm{nmol} /$ mouse, which corresponded to $0.007 \%$ of ingested anthocyanins.

\section{Discussion}

Numerous studies conducted in human subjects or animals have shown that total urinary excretion of anthocyanins is 


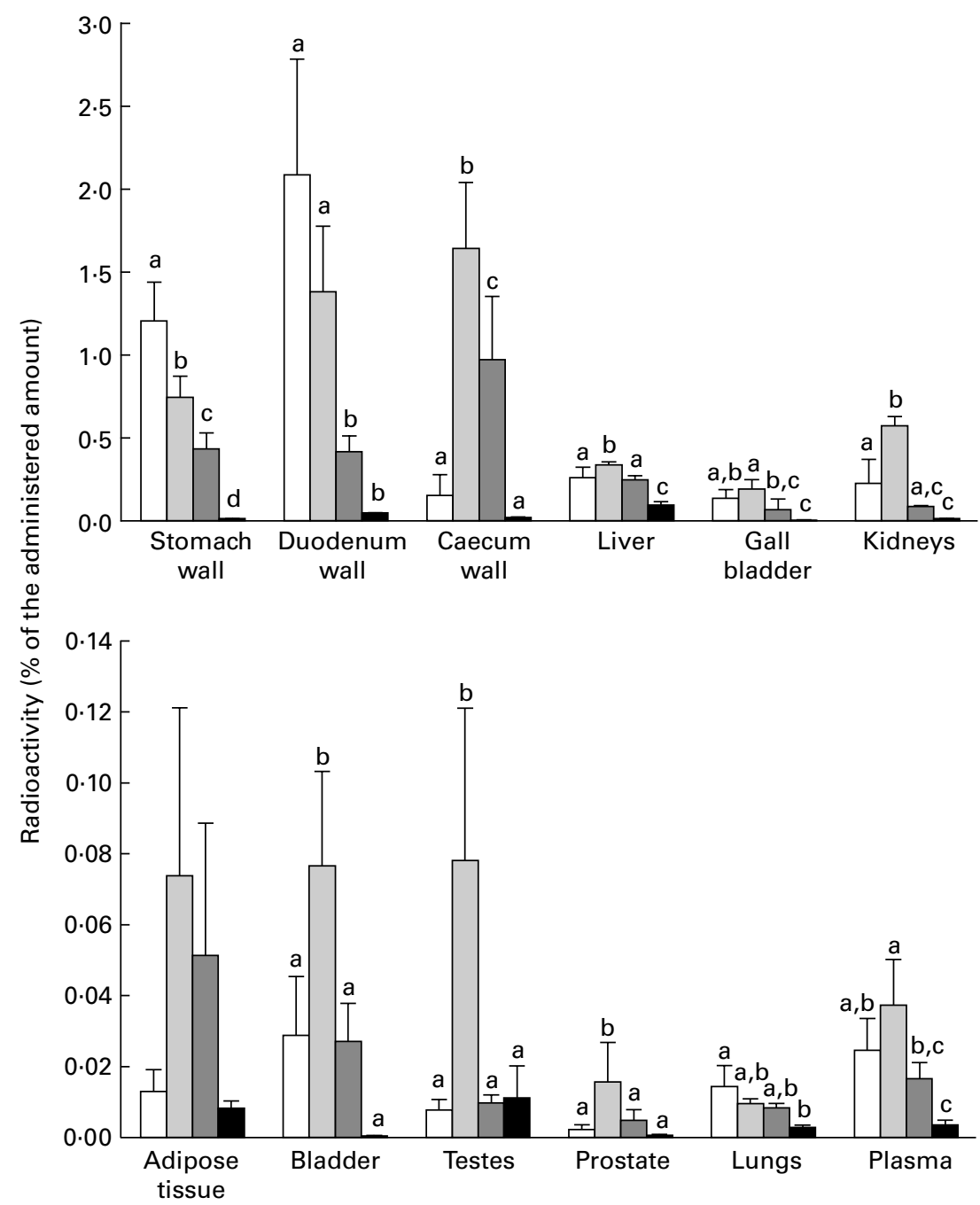

Fig. 2. Time course distribution of radioactivity in tissues after the ingestion of $22 \cdot 2 \mathrm{kBq}{ }^{14} \mathrm{C}$-cyanidin $3-O$-glucoside by mice. Mean values with their standard errors $(n)$. ${ }^{\text {a,b,c }}$ Mean values for a tissue with unlike superscript letters were significantly different $(P<0.05) . \square, 1 \mathrm{~h} 30 \mathrm{~min} ; \square, 3 \mathrm{~h} ; \square, 6 \mathrm{~h} ; \square, 24 \mathrm{~h}$.

typically $<0.1 \%$ of the administered dose (for review, see reference $\left.{ }^{(5)}\right)$. However, only a few authors have evaluated their distribution in body tissues and organs, and when this was the case, only parent compounds and their metabolites detectable at approximately $525 \mathrm{~nm}$ have been quantified $^{(20,22,23,25,34)}$. Oral administration of a labelled substrate such as ${ }^{14} \mathrm{C}-\mathrm{Cy} 3 \mathrm{G}$ used in the present study allows to follow the distribution of radioactivity in the body. Cy3G was labelled on its B-ring. ${ }^{14} \mathrm{C}$ will thus be present in all the anthocyanins and metabolites retaining the core flavonoid structure as well as in metabolites derived from the B-ring such as protocatechuic acid. Although quantification of radioactivity provided no information regarding the nature of the labelled metabolites, it allowed, however, to evaluate the amount of anthocyanin-derived metabolites distributed in the body more thoroughly. Excision of tissues was carried out in bloodless mice after perfusion of saline to remove residual blood in organs. Radioactivity detected in tissues was thus a reflection of the presence of anthocyanin derivatives in the tissues and not in the contaminating blood.

The distribution of ${ }^{14} \mathrm{C}-\mathrm{Cy} 3 \mathrm{G}$ and labelled metabolites in tissues was first examined over a $24 \mathrm{~h}$ period. In plasma and in most organs outside the GI tract, the highest amount of radioactivity was detected $3 \mathrm{~h}$ after oral administration of labelled Cy3G. Maximum plasma anthocyanin concentration was usually found between 15 and $30 \mathrm{~min}$ after anthocyanin administration in rats ${ }^{(23,24,35,36)}$. Moreover, a recent study

Table 1. Distribution of radioactivity in the gastrointestinal tract $3 \mathrm{~h}$ after oral administration of $141 \mathrm{kBq}$ of ${ }^{14} \mathrm{C}$ cyanidin 3-O-glucoside in mice

(Mean values with their standard errors for three mice)

\begin{tabular}{lccc}
\hline & \multicolumn{3}{c}{ Radioactivity } \\
\cline { 2 - 4 } Tissue & Mean $(\mathrm{kBq})$ & SEM $(\mathrm{kBq})$ & Intake $(\%)$ \\
\hline Stomach wall & 2.33 & 0.87 & 1.67 \\
Stomach content & 13.8 & 4.2 & 9.90 \\
Small intestine & 70.4 & 10.6 & 50.7 \\
Caecum wall & 2.55 & 0.83 & 1.84 \\
Caecum content & 29.2 & 10.8 & 21.1 \\
Colon wall & 0.58 & 0.25 & 0.42 \\
Colon content & 3.19 & 3.17 & 2.27 \\
Total & 122 & 2.7 & 87.9 \\
\hline
\end{tabular}


Table 2. Distribution of radioactivity in urine, plasma and tissues outside the gastrointestinal tract $3 \mathrm{~h}$ after oral administration of $141 \mathrm{kBq}$ of ${ }^{14} \mathrm{C}$ cyanidin 3 -O-glucoside in mice

(Mean values with their standard errors for three mice)

\begin{tabular}{|c|c|c|c|c|c|}
\hline \multirow[b]{2}{*}{ Tissue } & \multicolumn{5}{|c|}{ Radioactivity } \\
\hline & Mean (Bq/mg organ) & SEM (Bq/mg organ) & Mean $(\mathrm{Bq})$ & SEM $(B q)$ & Intake (\%) \\
\hline Urine from the bladder & & & 649 & 204 & 0.469 \\
\hline Urine from the cage & & & 3976 & 852 & $2 \cdot 86$ \\
\hline Total urine & & & 4626 & 652 & 3.33 \\
\hline Plasma & & & $61 \cdot 7$ & 4.6 & 0.044 \\
\hline Erythrocytes & & & $9 \cdot 76$ & 1.32 & 0.007 \\
\hline Liver & 0.35 & 0.01 & 373 & 20 & 0.268 \\
\hline Gallbladder + bile & $7 \cdot 81$ & 1.53 & 203 & 34 & 0.147 \\
\hline Kidneys & 0.58 & 0.03 & 198 & 6 & 0.143 \\
\hline Pancreas & 0.28 & 0.05 & $51 \cdot 0$ & $9 \cdot 6$ & 0.037 \\
\hline Lungs & $0 \cdot 15$ & 0.11 & 35.6 & $24 \cdot 3$ & 0.026 \\
\hline Bladder & 0.90 & 0.59 & 30.7 & $21 \cdot 7$ & 0.022 \\
\hline Adipose tissue & 0.07 & 0.02 & 20.5 & 4.0 & 0.015 \\
\hline Testes & $0 \cdot 10$ & 0.02 & $18 \cdot 0$ & 4.6 & 0.013 \\
\hline Prostate & 0.60 & 0.05 & 13.1 & 1.5 & 0.009 \\
\hline Heart & 0.07 & 0.01 & 9.41 & $2 \cdot 18$ & 0.007 \\
\hline Spleen & $0 \cdot 10$ & 0.01 & $6 \cdot 66$ & 0.90 & 0.005 \\
\hline Thymus & 0.17 & 0.08 & $6 \cdot 17$ & 2.51 & 0.004 \\
\hline Brain & 0.02 & 0.00 & $5 \cdot 84$ & 0.37 & 0.004 \\
\hline Muscle & 0.05 & 0.02 & $5 \cdot 29$ & 0.88 & 0.004 \\
\hline Cerebellum & 0.02 & 0.00 & 1.76 & 0.38 & 0.001 \\
\hline Eyes & 0.04 & 0.02 & 1.39 & 0.36 & 0.001 \\
\hline Total (except urine) & & & 1051 & 60 & 0.757 \\
\hline
\end{tabular}

carried out in mice has shown that in organs such as liver, kidney, lungs, heart and prostate, anthocyanin peak levels occurred within $30 \mathrm{~min}$ after oral administration of $500 \mathrm{mg} /$ $\mathrm{kg}$ body weight $\mathrm{Cy} 3 \mathrm{G}$ and decreased thereafter ${ }^{(26)}$. So, the peak of radioactivity observed $3 \mathrm{~h}$ after feeding was probably associated mainly to anthocyanin metabolites not detected at $524 \mathrm{~nm}$ which could in part result from anthocyanin skeleton degradation.

One and a half hours after feeding the radiolabelled anthocyanin, the bulk of the radioactivity was present in the upper part of the GI tract (stomach and duodenum). Then, the radioactivity progressed down the GI tract, and it was found in faeces from $6 \mathrm{~h}$ after anthocyanin intake. After $24 \mathrm{~h}$, faeces contained nearly half of the administered radioactivity $(45 \%)$. This radioactivity is more important than that detected in the faeces $24 \mathrm{~h}$ after the administration of $\left[2-{ }^{14} \mathrm{C}\right]$-quercetin $4^{\prime}$-glucoside in rats $(11 \% \text { of the administered amount })^{(37)}$. At the same time, the authors also found $64 \%$ of the administered radioactivity in urine. This radioactivity was associated with phenolic acids and other unknown metabolites, but not with quercetin conjugates ${ }^{(37)}$. The relatively large excretion of radioactivity in the faeces and low radioactivity in urine observed here for $\mathrm{Cy} 3 \mathrm{G}$, when compared to quercetin $4^{\prime}$-glucoside, reflects its relatively poor systemic bioavailability. The radioactivity found in the faeces corresponds mainly to anthocyanin degradation products since it has been reported in rats fed with various berries (raspberry, bilberry and chokeberry) that $<0.8 \%$ of the administered anthocyanins were recovered in faeces $12-24 \mathrm{~h}$ after their administration ${ }^{(38,39)}$. Various in vitro studies have shown that anthocyanins incubated with faecal microflora are degraded into phenolic acids originating from the anthocyanin B-ring, and into aldehydes derived from the A-ring ${ }^{(29-31,40)}$. As an example, $\mathrm{Cy} 3 \mathrm{G}$ is deglycosylated and degraded into protocatechuic
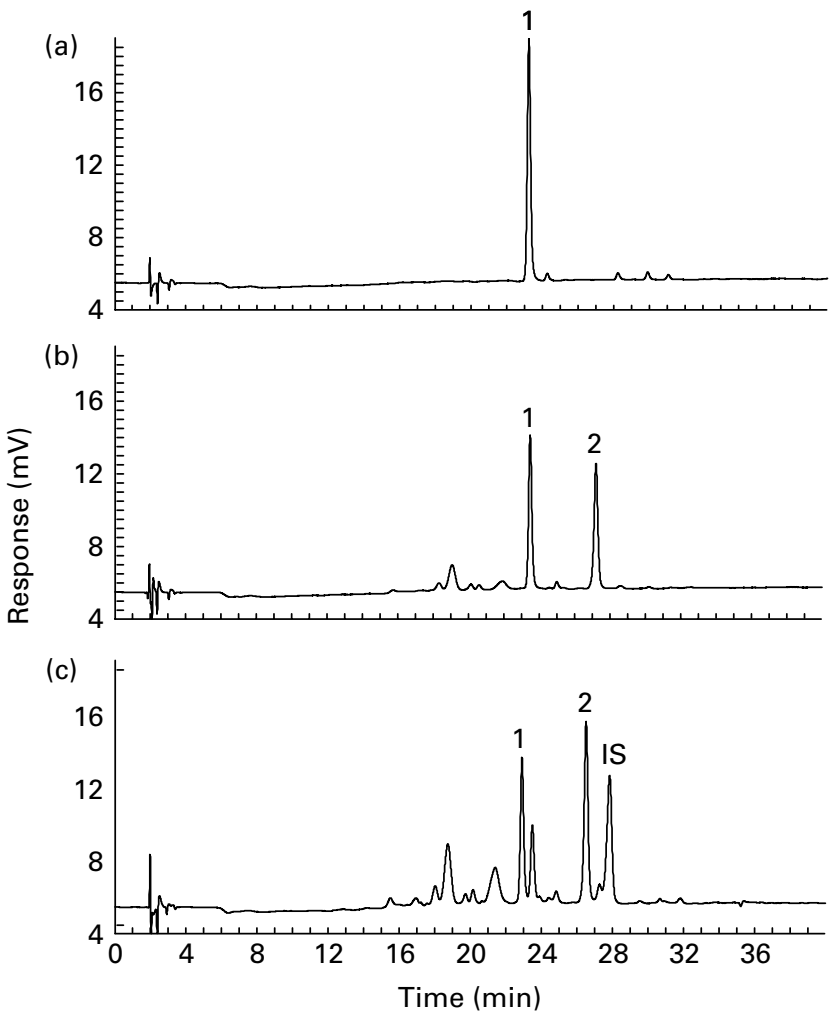

Fig. 3. HPLC chromatograms of blackberry anthocyanins (a) and urine (b) and plasma (c) collected from mice $3 \mathrm{~h}$ after oral administration of a blackberry anthocyanin solution. Detection was performed at $524 \mathrm{~nm}$. Peaks are as follows: 1, cyanidin 3-O-glucoside; 2 , methylated cyanidin 3-O-glucoside; IS, internal standard (malvidin 3-O-glucoside). 
acid and phloroglucinol aldehyde ${ }^{(30)}$. In human subjects, $28 \%$ of the ingested cyanidin glycosides are recovered as protocatechuic acid in the faeces ${ }^{(41)}$. A limitation of this investigation is the non-identification of phenolic acids. However, analytical determination of phenolic acids could not be carried out due to the limited sample size of mice.

After the administration of $22 \mathrm{kBq} /$ mouse, the amount of radioactivity present in some organs was very low, and thus it was difficult to determine it with accuracy. Thus, in order to evaluate the distribution of radioactivity more thoroughly, a higher amount of ${ }^{14} \mathrm{C}$-labelled Cy3G (141 kBq per animal) was administered to mice, and the animals were killed at the time of highest radioactivity in the inner tissues, i.e. $3 \mathrm{~h}$ after gavage. Most of the radioactivity ( $88 \%$ ) was still present in the GI tract (small intestine: $50.7 \%$ and caecum: $23 \%$ ), with the major part being in the digestive content. Nearly half of the administered radioactivity was found in the small intestine and is likely largely derived from Cy3G. Indeed, Borges et al. ${ }^{(38)}$ have shown that $3 \mathrm{~h}$ after raspberry anthocyanin ingestion by rats, $40 \%$ of the anthocyanins were in the ileum as their native forms, but only $2 \%$ were recovered in the caecum and colon. It could thus be suggested that the labelled compounds in the small intestine were principally anthocyanins, whereas the later parts of the GI tract mainly contained anthocyanin degradation products. Anthocyanins in the lumen of the upper GI tract may be stabilised by binding to mucus, secretions and food residues ${ }^{(42)}$. Their limited absorption in the gut and high concentrations in the GI tract could explain the chemoprevention against colorectal cancer as reported in rodents for various anthocyanin-rich extracts or berries ${ }^{(11,43-45)}$. Furthermore, in vitro studies on various colon cancer cell lines have shown antiproliferative actions of anthocyanins and anthocyanidins ${ }^{(46-49)}$. Microbial Cy $3 \mathrm{G}$ metabolites such as protocatechuic acid could also participate in the chemopreventive action of anthocyanins since this phenolic acid has been shown to inhibit the growth of human colon cancer cells ${ }^{(50)}$.

Three hours after anthocyanin feeding in mice, $1.1 \%$ of the administered blackberry anthocyanins (mainly $\mathrm{Cy} 3 \mathrm{G}$ ) were found in urine as metabolites with an intact flavylium skeleton (absorbing at $524 \mathrm{~nm}$ ). Urinary excretion of radiolabelled metabolites was higher $(3.3 \%)$ indicating that about twothird of the urinary metabolites did not possess a flavylium skeleton. Urinary excretion of the labelled metabolites was in the same order of magnitude as that reported after $\left[2-{ }^{14} \mathrm{C}\right]$-quercetin $4{ }^{\prime}$-glucoside administration in rats $(0.7$ and $6.8 \% 1$ and $6 \mathrm{~h}$ after feeding, respectively) ${ }^{(37)}$.

Minimal accumulation of radioactivity (approximately $3 \%$ ) was observed in tissues outside the GI tract $1-6 \mathrm{~h}$ after $\left[2-{ }^{14} \mathrm{C}\right]$-quercetin $4^{\prime}$-glucoside feeding to rats ${ }^{(37)}$. Similarly, we observed that the amount of radioactivity distributed to tissues beside the GI tract was very low, and that it accounted for only $0.76 \%$ of the administered dose $3 \mathrm{~h}$ after administration. Plasma contained about sixfold more labelled metabolites $\left(0.044 \%\right.$ of the administered $\left.{ }^{14} \mathrm{C}\right)$ than anthocyanin metabolites with intact flavylium skeleton absorbing at $524 \mathrm{~nm}$ ( $0.007 \%$ of the non-labelled blackberry anthocyanins). Protocatechuic acid was described as a major anthocyanin metabolite in various in vitro studies ${ }^{(29-31)}$ and in human plasma $^{(41)}$. However, its presence in rat plasma after Cy3G oral administration remains controversial. Whereas Tsuda et al. (36) found protocatechuic acid in plasma at a concentration almost eight times higher than that of $\mathrm{Cy} 3 \mathrm{G}$, Ichiyanagi et al. ${ }^{(51)}$ failed to detect this phenolic acid in plasma. Labelled metabolites without intact flavylium skeleton could correspond to protocatechuic acid as well as to other colourless unidentified metabolites.

Large differences in radioactivity concentration were observed between tissues. The high amount of radioactivity in liver, gallbladder, kidney and bladder is probably caused by the excretion of some anthocyanin metabolites into the bile $^{(18)}$ and urine. We have previously reported a relatively high anthocyanin concentration in rat kidney and blad$\operatorname{der}^{(20,25)}$. A high concentration of labelled metabolites was also observed in the prostate. Anthocyanins were shown to be cytotoxic and to induce apoptosis in prostate cancer cells $\mathrm{s}^{(4,52-54)}$. By accumulation of their various metabolites in this gland, anthocyanins could thus play a role in the prevention of prostate cancer.

Low radioactivity was also found in pancreas, lungs and thymus, and very low radioactivity was found in other organs such as heart, adipose tissue, brain and eyes. We have detected previously small amounts of $\mathrm{Cy} 3 \mathrm{G}$ and its metabolites in brain, adipose tissue, testes and heart from rats fed with blackberry anthocyanins ${ }^{(20,25)}$. When fed to mice, bilberry anthocyanins were also found in liver, kidney, testes and lungs, whereas no detectable levels were found in heart, thymus, brain, white fat and eyes ${ }^{(27)}$.

Altogether, $92 \%$ of the administered radioactivity could be recovered from the various tissues and fluids $3 \mathrm{~h}$ after ${ }^{14} \mathrm{C}-\mathrm{Cy} 3 \mathrm{G}$ feeding. The remaining radioactivity may be distributed in tissues that were not collected such as skeletal muscles, skin, bone and most of the adipose tissues. Indeed, all the analysed tissues accounted for $<25 \%$ of the mouse whole body weight. Moreover, the high overall recovery of radioactivity suggests that losses through degradation into ${ }^{14} \mathrm{CO}_{2}$ are, at best, minimal at this time. This is in accordance with the recent study of Mullen et al. ${ }^{(37)}$ carried out on rats receiving $\left[2-{ }^{14} \mathrm{C}\right]$-quercetin $4{ }^{\prime}$-glucoside, but it contrasts with the study of Walle et al. ${ }^{(55)}$ where $52 \%$ of the radioactivity from $\left[4-{ }^{14} \mathrm{C}\right]$-quercetin was recovered in the expired air as ${ }^{14} \mathrm{CO}_{2}$ in human subjects.

In conclusion, the present study is the first one to describe the distribution of the metabolites derived from a radiolabelled anthocyanin in the body. Most of the radiolabelled metabolites $(88 \%)$ were present in the digestive tract, and only small amounts were found in inner tissues, confirming the limited systemic bioavailability of anthocyanins. There was thus minimal accumulation of radioactivity in tissues outside the GI tract. The radioactivity found in various tissues may correspond not only to labelled anthocyanins and their metabolites with intact flavylium skeleton, but also to other metabolites that remain to be identified.

\section{Acknowledgements}

C. F., O. T. and A. S. designed the research and wrote the paper. C. F., O. T., S. K., A. M. and C. B. conducted the research. S. K. and J.-M. M. provided the essential materials, and A. S., J.-L. L. and J.-M. M. managed the implicated laboratories. The authors have no conflicts of interest to disclose. The present work has no funding. 


\section{References}

1. Clifford MN (2000) Anthocyanins - nature, occurrence and dietary burden. J Sci Food Agric 80, 1063-1072.

2. Wu X, Beecher GR, Holden JM, et al. (2006) Concentrations of anthocyanins in common foods in the United States and estimation of normal consumption. J Agric Food Chem 54, 4069-4075.

3. Ovaskainen ML, Torronen R, Koponen JM, et al. (2008) Dietary intake and major food sources of polyphenols in Finnish adults. J Nutr 138, 562-566.

4. Erdman JW Jr, Balentine D, Arab L, et al. (2007) Flavonoids and heart health: proceedings of the ILSI North America Flavonoids Workshop, May 31-June 1, 2005, Washington, DC. J Nutr 137, 718S-737S.

5. Galvano F, La Fauci L, Vitaglione P, et al. (2007) Bioavailability, antioxidant and biological properties of the natural free-radical scavengers cyanidin and related glycosides. Ann Ist Super Sanita 43, 382-393.

6. Prior RL \& Wu X (2006) Anthocyanins: structural characteristics that result in unique metabolic patterns and biological activities. Free Radic Res 40, 1014-1028.

7. Cooke D, Steward WP, Gescher AJ, et al. (2005) Anthocyans from fruits and vegetables - does bright colour signal cancer chemopreventive activity? Eur J Cancer 41, 1931-1940.

8. Xia X, Ling W, Ma J, et al. (2006) An anthocyanin-rich extract from black rice enhances atherosclerotic plaque stabilization in apolipoprotein E-deficient mice. J Nutr 136, 2220-2225.

9. Zafra-Stone S, Yasmin T, Bagchi M, et al. (2007) Berry anthocyanins as novel antioxidants in human health and disease prevention. Mol Nutr Food Res 51, 675-683.

10. Tarozzi A, Morroni F, Hrelia S, et al. (2007) Neuroprotective effects of anthocyanins and their in vivo metabolites in $\mathrm{SH}$ SY5Y cells. Neurosci Lett 424, 36-40.

11. Misikangas M, Pajari AM, Paivarinta E, et al. (2007) Three nordic berries inhibit intestinal tumorigenesis in multiple intestinal neoplasia/+ mice by modulating beta-catenin signaling in the tumor and transcription in the mucosa. J Nutr 137, 2285-2290.

12. Tsuda T, Horio F, Uchida K, et al. (2003) Dietary cyanidin 3-O-beta-D-glucoside-rich purple corn color prevents obesity and ameliorates hyperglycemia in mice. $J$ Nutr $\mathbf{1 3 3}$, 2125-2130.

13. Prior RL, Wu X, Gu L, et al. (2008) Whole berries versus berry anthocyanins: interactions with dietary fat levels in the C57BL/ 6J mouse model of obesity. J Agric Food Chem 56, 647-653.

14. McGhie TK \& Walton MC (2007) The bioavailability and absorption of anthocyanins: towards a better understanding. Mol Nutr Food Res 51, 702-713.

15. Felgines C, Talavéra S, Gonthier MP, et al. (2003) Strawberry anthocyanins are recovered in urine as glucuro- and sulfoconjugates in humans. $J$ Nutr 133, 1296-1301.

16. Kay CD, Mazza GJ \& Holub BJ (2005) Anthocyanins exist in the circulation primarily as metabolites in adult men. $J$ Nutr 135, 2582-2588.

17. Wu X, Pittman HE 3rd, McKay S, et al. (2005) Aglycones and sugar moieties alter anthocyanin absorption and metabolism after berry consumption in weanling pigs. $J$ Nutr $\mathbf{1 3 5}$, 2417-2424.

18. Talavéra S, Felgines C, Texier O, et al. (2004) Anthocyanins are efficiently absorbed from the small intestine in rats. J Nutr 134, 2275-2279.

19. Talavéra S, Felgines C, Texier O, et al. (2003) Anthocyanins are efficiently absorbed from the stomach in anesthetized rats. J Nutr 133, 4178-4182.

20. Talavéra S, Felgines C, Texier O, et al. (2005) Anthocyanin metabolism in rats and their distribution to digestive area, kidney, and brain. J Agric Food Chem 53, 3902-3908.
21. Matsumoto H, Nakamura $\mathrm{Y}$, Iida $\mathrm{H}$, et al. (2006) Comparative assessment of distribution of blackcurrant anthocyanins in rabbit and rat ocular tissues. Exp Eye Res 83, 348-356.

22. Kalt W, Blumberg JB, McDonald JE, et al. (2008) Identification of anthocyanins in the liver, eye, and brain of blueberry-fed pigs. J Agric Food Chem 56, 705-712.

23. Ichiyanagi T, Shida Y, Rahman MM, et al. (2006) Bioavailability and tissue distribution of anthocyanins in bilberry (Vaccinium myrtillus L.) extract in rats. J Agric Food Chem 54, 6578-6587.

24. Hassimotto NMA, Genovese MI \& Lajolo FM (2008) Absorption and metabolism of cyanidin-3-glucoside and cyanidin-3-rutinoside extracted from wild mulberry (Morus nigra L.) in rats. Nutr Res $\mathbf{2 8}$, 198-207.

25. Felgines C, Texier O, Garcin P, et al. (2009) Tissue distribution of anthocyanins in rats fed a blackberry anthocyanin-enriched diet. Mol Nutr Food Res 53, 1098-1103.

26. Marczylo TH, Cooke D, Brown K, et al. (2009) Pharmacokinetics and metabolism of the putative cancer chemopreventive agent cyanidin-3-glucoside in mice. Cancer Chemother Pharmacol 64, 1261-1268.

27. Sakakibara H, Ogawa T, Koyanagi A, et al. (2009) Distribution and excretion of bilberry anthocyanines in mice. J Agric Food Chem 57, 7681-7686.

28. Mazza G \& Miniati E (1993) Anthocyanins in Fruits, Vegetables, and Grains. Boca Raton, FL: CRC Press.

29. Aura AM, Martin-Lopez P, O'Leary KA, et al. (2005) In vitro metabolism of anthocyanins by human gut microflora. Eur $J$ Nutr 44, 133-142.

30. Keppler K \& Humpf HU (2005) Metabolism of anthocyanins and their phenolic degradation products by the intestinal microflora. Bioorg Med Chem 13, 5195-5205.

31. Fleschhut J, Kratzer F, Rechkemmer G, et al. (2006) Stability and biotransformation of various dietary anthocyanins in vitro. Eur J Nutr 45, 7-18.

32. Vitrac X, Krisa S, Decendit A, et al. (2002) Carbon-14 biolabelling of wine polyphenols in Vitis vinifera cell suspension cultures. J Biotechnol 95, 49-56.

33. Springob K, Nakajima J, Yamazaki M, et al. (2003) Recent advances in the biosynthesis and accumulation of anthocyanins. Nat Prod Rep 20, 288-303.

34. El Mohsen MA, Marks J, Kuhnle G, et al. (2006) Absorption, tissue distribution and excretion of pelargonidin and its metabolites following oral administration to rats. Br J Nutr 95, 51-58.

35. Ichiyanagi T, Shida Y, Rahman MM, et al. (2005) Metabolic pathway of cyanidin 3-O-beta-D-glucopyranoside in rats. $J$ Agric Food Chem 53, 145-150.

36. Tsuda T, Horio F \& Osawa T (1999) Absorption and metabolism of cyanidin 3-O-beta-D-glucoside in rats. FEBS Lett 449, 179-182.

37. Mullen W, Rouanet JM, Auger C, et al. (2008) Bioavailability of [2-(14)C]quercetin-4'-glucoside in rats. J Agric Food Chem 56, 12127-12137.

38. Borges G, Roowi S, Rouanet JM, et al. (2007) The bioavailability of raspberry anthocyanins and ellagitannins in rats. Mol Nutr Food Res 51, 714-725.

39. He J, Magnuson BA \& Giusti MM (2005) Analysis of anthocyanins in rat intestinal contents - impact of anthocyanin chemical structure on fecal excretion. J Agric Food Chem 53, 2859-2866.

40. Forester SC \& Waterhouse AL (2008) Identification of Cabernet Sauvignon anthocyanin gut microflora metabolites. J Agric Food Chem 56, 9299-9304.

41. Vitaglione P, Donnarumma G, Napolitano A, et al. (2007) Protocatechuic acid is the major human metabolite of cyanidinglucosides. J Nutr 137, 2043-2048. 
42. He J, Wallace TC, Keatley KE, et al. (2009) Stability of black raspberry anthocyanins in the digestive tract lumen and transport efficiency into gastric and small intestinal tissues in the rat. J Agric Food Chem 57, 3141-3148.

43. Cooke D, Schwarz M, Boocock D, et al. (2006) Effect of cyanidin-3-glucoside and an anthocyanin mixture from bilberry on adenoma development in the ApcMin mouse model of intestinal carcinogenesis-relationship with tissue anthocyanin levels. Int $J$ Cancer 119, 2213-2220.

44. Bobe G, Wang B, Seeram NP, et al. (2006) Dietary anthocyanin-rich tart cherry extract inhibits intestinal tumorigenesis in APC(min) mice fed suboptimal levels of sulindac. J Agric Food Chem 54, 9322-9328.

45. Lala G, Malik M, Zhao C, et al. (2006) Anthocyanin-rich extracts inhibit multiple biomarkers of colon cancer in rats. Nutr Cancer 54, 84-93.

46. Zhang Y, Vareed SK \& Nair MG (2005) Human tumor cell growth inhibition by nontoxic anthocyanidins, the pigments in fruits and vegetables. Life Sci 76, 1465-1472.

47. Zhang Y, Seeram NP, Lee R, et al. (2008) Isolation and identification of strawberry phenolics with antioxidant and human cancer cell antiproliferative properties. J Agric Food Chem 56, 670-675.

48. Yun JM, Afaq F, Khan N, et al. (2009) Delphinidin, an anthocyanidin in pigmented fruits and vegetables, induces apoptosis and cell cycle arrest in human colon cancer HCT116 cells. Mol Carcinog 48, 260-270.
49. Renis M, Calandra L, Scifo C, et al. (2008) Response of cell cycle/stress-related protein expression and DNA damage upon treatment of $\mathrm{CaCo}_{2}$ cells with anthocyanins. Br J Nutr 100, 27-35.

50. Hudson EA, Dinh PA, Kokubun T, et al. (2000) Characterization of potentially chemopreventive phenols in extracts of brown rice that inhibit the growth of human breast and colon cancer cells. Cancer Epidemiol Biomarkers Prev 9, 1163-1170.

51. Ichiyanagi T, Rahman MM, Hatano Y, et al. (2007) Protocatechuic acid is not the major metabolite in rat blood plasma after oral administration of cyanidin 3-O- $\beta$-D-glucopyranoside. Food Chem 105, 1032-1039.

52. Munoz-Espada AC \& Watkins BA (2006) Cyanidin attenuates PGE2 production and cyclooxygenase-2 expression in LNCaP human prostate cancer cells. J Nutr Biochem 17, 589-596.

53. Reddivari L, Vanamala J, Chintharlapalli S, et al. (2007) Anthocyanin fraction from potato extracts is cytotoxic to prostate cancer cells through activation of caspase-dependent and caspase-independent pathways. Carcinogenesis $\mathbf{2 8}$, 2227-2235.

54. Hafeez BB, Siddiqui IA, Asim M, et al. (2008) A dietary anthocyanidin delphinidin induces apoptosis of human prostate cancer PC3 cells in vitro and in vivo: involvement of nuclear factor-kappaB signaling. Cancer Res 68, 8564-8572.

55. Walle T, Walle UK \& Halushka PV (2001) Carbon dioxide is the major metabolite of quercetin in humans. J Nutr 131, $2648-2652$. 